schools in agricultural districts might well offer to lads who have passed through the successive standards, or as one addressed to the sons of farmers, and supplying that form of instruction which it is the duty of agricultural colleges to impart. Another lecture is offered on the management of poultry. This is more definite and more hopeful; and when we remember that the students who come up for these summer meetings are, for the most part, ladies, who can well be supposed to take an intelligent interest in this part of farming operations, we must admit that the subject is well chosen. Manures of various characters form the subject of the other two lectures, and will be doubtless of a sufficiently technical character.

The literature and history lectures are of special interest, and by the combination of many lecturers are made to cover with great completeness the mediæval period. Mr. Frederic Harrison gives, as an inaugural lecture, a survey of the thirteenth century, and strikes the keynote of this section; while in the entire course, which embraces some sixty lectures, we meet the names of Prof. Dicey, of Mr. York Powell, of Mr. Boas, and a host of others, affording alike a sufficient guarantee for the excellence of the work, and a happy augury for the success of the meeting.

\section{THE PROPOSED TEACHING UNIVERSITY FOR LONDON.}

$\mathrm{O}^{\mathrm{N}}$ $\mathrm{N}$ Monday, at the Council Office in Downing Street the Universities Committee of the Privy Council, consisting of the Lord President of the Council (Viscount Cranbrook), the Earl of Selborne, Lord Monk Bretton, Lord Basing, and Lord Sandford, reassembled for the purpose of giving their decision on the petition of King's and University Colleges for the grant of a charter for the establishment of a Teaching University for London.

The Earl of Selborne, in giving the opinion of their Lordships upon the draft charter of the proposed University, said, with regard to the opposition of the existing University of London, that some of the objections made might be treated as disallowed. It had been understood by their Lordships that a minimum course of two years' study at the new University would be required. If that was so, their Lordships were satisfied, and would say no more upon the point. The objections put forward by the medical faculty were generally disallowed. The word "London" would have to be omitted from the charter, but the University might be called either "the Albert University" or "the Metropolitan University." With regard to the suggestion that ten members of the Faculty of Medicine should be elected to the Council, their Lordships were of opinion that the medical schools should fill five places upon that body, or, if it were preferred, that each school should elect one member for the Medical Board of Study. If the Royal Colleges and the medical schools agreed to come in together, however, the number of members on the Council might be raised. Their Lordships did not approve of the proposed strength of the Council, and thought that four of the places might be accorded to the Faculty of Law. Teachers in any branch of science, their Lordships considered, should be admitted as members of the Science Faculty, and the six places on the Council which it was proposed to give to the Royal Colleges should be supplied according to the 29th paragraph of the Royal Commissioners' Report. If the medical schools and colleges declined to come in at first, provision ought to be made to allow them to do so in the future. Their Lordships thought that a place upon the Council might be given to the Apothecaries' Society, but they were not disposed to insist upon that being done The view of their Lordships upon the question of honorary degrees was that no such degrees should be granted in medicine, and that the holding of an honorary degree should be no qualification for election to the Council. The ordinary degree in medicine should not be granted until the whole of the prescribed conditions had been fulfilled.

\section{NOTES.}

Trie decision of the Universities Committee of the Privy Council with regard to the proposed new University for London is one that might have been expected from a body of non-experts. It is hasty, and will give satisfaction to no one by whom the subject has been seriously considered. It may throw back the higher teaching in London for half a century.

Mr. WALter BeSANT, in an imaginary "Page from the Kaiser's Diary," notes that there are not to be seen at Court any of "the people who make the real greatness of the country -its traders, its manufacturers, its men of science, art, and literature." It has been remarked that in this respect the City Corporation, last Friday, followed the example of the Court, no representative of science, or literature, or art, as such, having been invited to the Guildhall banquet. It would have been better to follow the precedent set at the time of the Czar's visit, when a large number of the leading scientific men were asked to the reception at the Foreign Office, and were personally presented.

AT the ensuing British Association meeting at Cardiff, it is proposed to hold in Section A, if possible in conjunction with Section G, a discussion on "Units and their Nomenclature," having special regard to the new electrical and magnetic units now becoming necessary for practical purposes.

ThE Secretary of State for India in Council has appointed, on the nomination of the Government of India, the following persons to represent it on the permanent governing body of the Imperial Institute, for the year ending April 30, 1892 :W. T. Thiselton-Dyer, C.M.G., F.R.S., Director, Royal Gardens, Kew ; General James T. Walker, R.E., C.B., F.R.S., late Surveyor-General of India; John W. P. Muir-Mackenzie, Under-Secretary to the Government of India Revenue and Agricultural Department.

Sir J. D. Hooker has been elected a Foreign Member of the Academy of Sciences in Buda-Pesth.

THE Secretary of State for the Colonies has appointed, on the nomination of Kew, Mr. C. A. Barber, late Scholar of Christ's College, Cambridge, and University Demonstrator in Botany, to be Superintendent of the recently created Agricultural Department of the Leeward Islands. The Superintendent will reside in Antigua, and will have the general supervision of the botanical stations at Antigua, Dominica, Montserrat, and St. Kitts-Nevis.

THE Council of University College, Liverpool, have appointed Mr. Francis Gotch, of Oxford, to their new Chair of Physiology.

THE Foreign Office has expressed the wish that the "Flora of Tropical Africa," prepared at Kew under the editorship of Prof. Oliver, and of which three volumes have appeared, should be continued and completed. It is calculated that four more volumes will be required, and the Treasury has sanctioned a scheme by which the necessary funds will be provided.

THE Accademia dei Lincei of Rome has awarded to Prof Saccardo, of Padua, in acknowledgment of his labours in mycology, the Royal prize of 10,000 francs intended for the encouragement of morphological researches. NO. 1 I 33 , VOL. 44] 